Egyptian Veterinary Medical Society of Parasitology Journal

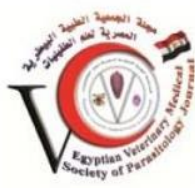

\title{
Original Article \\ Prevalence and Phylogenetic analysis of Fasciola species in Upper Egypt Based on Ribosomal ITS- 2 gene Sequencing
}

\begin{abstract}
Ahmed G. Abdelazeem ${ }^{1}$, Amer Ragheb Abdelaziz ${ }^{2}$, Reda E. Khalafalla ${ }^{3 @}$ Mostafa F.N. Abushahba ${ }^{4}$,

${ }^{1}$ Department of Parasitology, Faculty of Veterinary Medicine, Aswan University, Egypt.

${ }^{2}$ Department of Parasitology, Faculty of Veterinary Medicine, Sohag University, 82524, Egypt.

${ }^{3 @ D e p a r t m e n t ~ o f ~ P a r a s i t o l o g y, ~ F a c u l t y ~}$ of Veterinary Medicine, Kafrelsheikh University, Kafr El-Sheikh, 33516, Egypt.

${ }^{4}$ Department of Zoonoses, Faculty of Veterinary Medicine, Assiut University, 71526, Egypt.

${ }^{5}$ Department of Medicine, Division of Infectious Diseases, Washington University School of Medicine, St. Louis, MO 63110, USA.

${ }^{\circledR}$ Corresponding Author E-Mail: redabast@hotmail.de, Tel.:

+201028129746 Fax: +20473231311 Department of Parasitology, faculty of Veterinary Medicine, Kafrelsheikh University, Kafr El-Sheikh, 33516 , Egypt.
\end{abstract}

\begin{abstract}
:
Fascioliasis is an important parasitic zoonosis with an estimated annual economic loss at more than US $\$ 3$ billion in animals and infection risk in more than 180 million people worldwide. Given the economic and public health significance of this trematode, a periodical evaluation of its prevalence and the associated risk factors as well as the evolutionary relatedness is needed. Here, 1560 cattle and 1630 goat livers were examined for the presence of adult Fasciola among animals slaughtered in slaughterhouses of at Assiut and Sohag Governorates, Upper Egypt. Molecular characterization and phylogenetic relationships were determined based on the second internal transcribed spacer (ITS-2) of nuclear ribosomal DNA (rDNA). The overall prevalence of fasciolosis was based on morphological identification of the recovered Fasciola adult worms and the prevalence was $5.1 \%$ and $3.5 \%$ among cattle and goats, respectively. Though the age, gender, and housing system significantly affected the disease in cattle, none of these variables had a significant impact on goat fasciolosis. Nonetheless, the sampled goats were found at increased risk of being infected with Fasciola hepatica as the age increases and when the winter season emerges. Phylogenetic analyses showed that both Fasciola gigantica and Fasciola hepatica sequenced in this study had a common ancestor and they fall in one clade with several previously reported Egyptian and worldwide fasciolae from animals and humans. This study demonstrates that the disease is currently circulating among animals in Assiut and Sohag Governorates that warrants the urgent need for application of the appropriate control measures as well as evaluating the possible ongoing zoonotic burden in people residing such areas.
\end{abstract}

Keywords: Cattle, goats, Fasciola, Prevalence, Zoonosis, ITS2, Molecular characterization, Upper Egypt.

\section{INTRODUCTION}

Fasciolosis is a worldwide parasitic (Platyhelminthes: Trematoda: Digenea) zoonosis affecting animals and humans. It was considered as a historical disease for long time; however, the disease has been recently categorized as one of the reemerging zoonosis with an estimate of up to 2.4 million people are affected by fascioliasis in more than seventy countries across the globe (Mas-Coma et al., 2005).

In mammals, the infection occurs by ingestion of the encysted metacercariae on fresh water plants and water (Mas-Coma et 
al., 2005). The immature flukes take several weeks wandering in the liver parenchyma of the affected host, makes the parasite highly tissue destructive, before residing in the bile duct and progressing to the adult stage. To complete the lifecycle, adult flukes produce eggs which are voided with feces and contaminate fresh water where they undergone the necessary developmental stages with the aid of the fresh water snails (Nyindo and Lukambagire, 2015). Indeed, fascioliasis is a multifactorial disease with limited treatment choices and no vaccine; hence, application of strict measures remains important solution to effectively combat such foodborne zoonotic disease (Knubben-Schweizer and Torgerson, 2015).

The disease is mainly caused by $F$. hepatica Linnaeus, 1758 , and $F$. gigantica Cobbold, 1856, both can utilize animals and humans as definitive hosts (Amer et al., 2016). Identification of these parasites is usually based on the Morphological and morphometric criteria, however, these traditional methods remain unreliable in definite differentiation (Liu et al., 2014; Moghaddam et al., 2004). For that, molecular methods are required in resolving the difficulties associated with species identification based on the phenotypic traits (Shoriki et al., 2016). One of these methods widely used to differentiate between $F$. gigantica and $F$. hepatica is the second internal transcribed spacer (ITS-2) of nuclear rDNA which found to have $1.7 \%$ sequence difference between the two Fasciola species and very low differences within each species (Choe et al., 2011; Hashimoto et al., 1997; Itagaki et al., 2005; Lin et al., 2007; Liu et al., 2014; Marcilla et al., 2002).
Egypt is considered as one of the fasciolosis endemic countries in the world and of high parasitic burden in infected animals and humans (Arafa et al., 2017; Haridy et al., 2006); nevertheless, epidemiological data about the disease in Upper Egypt are scarce and the molecular characterization studies on important hosts like cattle and more particularly goats are severely underappreciated. Therefore, this study was mainly designed to clarify the prevalence Fasciola species and associated risk factors of infection among cattle and goats. In addition, the identity, genetic characterization and phylogenetic analysis of nuclear ribosomal internal transcribed spacer gene (ITS-2 region of rDNA) in Fasciola species, among slaughtered cattle and goats from Assiut and Sohag abattoirs in Upper Egypt.

\section{Materials and Methods}

\subsection{Research ethics:}

Approval of ethical rules was followed after a Research guidance, Publication and Ethics of the Faculty of Veterinary Medicine, Sohag University (2014). All steps of the study were clarified to abattoirs authorities, veterinarians, and owners. The living animals were not included in the study.

\subsection{Area of the study}

Samples were collected from livers of slaughtered animals at routine postmortem examination in Assiut $\left(27.252^{\circ} \mathrm{N} 31.09^{\circ} \mathrm{E}\right)$ and Sohag $\left(26^{\circ} 33^{\prime} \mathrm{N} 31^{\circ} 42^{\prime} \mathrm{E}\right)$ abattoirs from January to October 2019.

\subsection{Sample size:}

Based on a previously published study in El Minia Governorate, one of the most nearest governorates to the survey areas, reported an infection rate of $35 \%$ in cattle and utilizing the equation: $n=Z^{2} \times P \times q / d^{2}$

(Charan and Biswas, 2013), a minimum 
sample size equal to 350 or 606 animals using $5 \%$ or $1 \%$ type 1 errors, respectively was sufficient. In goats, with the scarcity of data about the disease in Upper Egypt, we calculated the sample size based on assumption of $50 \%$ prevalence and it was found to be 384 or 666 using $5 \%$ or $1 \%$ type 1 error, respectively. However, to ensure more power for the current study, we considered a greater sample size accounted for 1560 cattle and 1630 livers recruited from slaughtered cattle and goats, respectively.

\subsection{The parasite:}

During the period from January to October 2019, a total of 3190 livers of slaughtered animals (1560 cattle and 1630 goats) were examined at necropsy and were labeled (animal species, location, age, season, sex, and rearing system). The collected adult Fasciola species flukes were transported on ice to the laboratory of the department of parasitology in Assuit university and Sohag University, washed with physiological saline, relaxed, fixed in $10 \%$ neutral formalin, stained with alumcarmine and mounted for morphological identification (Soulsby, 1982). Another portion of collected liver flukes was kept in $70 \%$ ethanol for extraction of genomic DNA (Huang et al., 2004).

\subsection{DNA extraction and PCR conditions:}

Ten of morphologically identified positive samples of $F$. gigantia and 10 identified positive samples of $F$. hepatica were selected for DNA extraction afterwards, five adult flukes from each sample were consumed for DNA extraction by using QIAamp DNA Mini Kit (QIAgen, Hilden, Germany) following the manufacturer's guidelines. Specific primers for the amplification of the ITS-2 regions were

used:

$\mathrm{F}$ :

5'GGTACCGGTGGATCACTCGGCTCGTG3' and

$\mathrm{R}$ :

5'GGGATCCTGGTTAGTTTCTTTTCCTCCG

C3' (Luton et al., 1992).

The PCR amplification protocol was performed in a final reaction volume of $25 \mu$; $12.5 \mu \mathrm{l}$ Master Mix (Promega, Madison, WI, USA), $1 \mu$ forward primer, $1 \mu$ reverse primer, $1 \mu$ l extracted genomic DNA (50 ng) and $9.5 \mu \mathrm{l}$ deionized distilled water (White, 1993). The PCR reaction was performed in Biometra thermocycler (Biometra, Gottingen, Germany) as follows; initial denaturation at $95{ }^{\circ} \mathrm{C}$ for $5 \mathrm{~min}$ followed by 40 cycles of denaturation at $95{ }^{\circ} \mathrm{C}$ for $30 \mathrm{sec}$, annealing at $60{ }^{\circ} \mathrm{C}$ for $30 \mathrm{sec}$ and primer extension at 72 ${ }^{\circ} \mathrm{C}$ for $1 \mathrm{~min}$ followed by a final extension at $72{ }^{\circ} \mathrm{C}$ for $10 \mathrm{~min}$. Thereafter, using 100 base pair plus ladder (DNA Molecular Weight Marker), the PCR products were electrophoresed in 1.6\% (w/v) agarose gels in Tris-acetate-EDTA (TAE) buffer, stained with ethidium bromide and visualized and photographed by UV trans-illuminator.

\subsection{ITS2 Sequencing and analysis:}

PCR products were purified using Qiagen QIAquick PCR Purification kit following the manufacturer instructions. The purified PCR products of ITS-2 were sequenced by applying the same forward primers in an automated sequencer (ABI PRISM® 310 genetic analyzer, available at Molecular Biology Unit, Assiut University) following manufacturer instructions. The sequences identities were confirmed utilizing BLAST (the online tool provided by NCBI; https://blast.ncbi.nlm.nih.gov/Blast.cgi?PROG RAM=blastn\&PAGE_TYPE=BlastSearch\&LIN K_LOC=blasthome, Zheng Zhang, et al., 2000). Alignment of the current ITS-2 sequences with corresponding sequences obtained from the NCBI was further 
computed using ClustalW (Madeira et al., 2019) and the evolutionary analyses were conducted in MEGA $X$ (Kumar et al., 2018). The evolutionary history was inferred by using the Maximum Likelihood method and Tamura-Nei model (Tamura and Nei, 1993). Initial trees for the heuristic search were obtained by applying the Neighbor-Joining method to a matrix of pairwise distances estimated using the Tamura-Nei model. The analyses involved 15 and 16 nucleotide sequences in cases of F. gigantica and F. hepatica, respectively. Fasciola jacksoni (MN970006.1) and Fascioloides magna (KU232369.1) were used as outgroup isolates.

\subsection{Statistical analysis}

Fisher's Exact test, Odds ratio (OR) with 95\% Confidence Intervals (95\% Cl) in GraphPad Prism software version 6 (GraphPad Software, Inc., La Jolla, CA, USA) were used to compute the categorical variables included in this study. A $P$ value $<0.05$ was considered significant.

\section{Results}

In the present study, the overall prevalence of $F$. gigantica infection in cattle was $5.06 \%$ and $F$. hepatica infection in goats was $3.5 \%$. Cattle's age, gender and rearing system significantly affected the prevalence of fasciolosis with $P$ values equal to $0.048,0.035$ and $<0.0001$, respectively. OR (Odds ratio) showed remarkable differences between the subcategories of such significant variables. For instance, regarding cattle's age, animals older than 4 years showed the highest $\mathrm{OR}(\mathrm{OR}=1.93(95 \% \mathrm{Cl}$ : $1.14-$ 3.28)) followed by $1-2$ years old animals $(\mathrm{OR}=1.50(95 \% \mathrm{Cl}: 0.80-2.82))$. Likewise, female cattle had a higher odds of exposure $(\mathrm{OR}=1.64(95 \mathrm{Cl}: 1.04-2.58))$ relative to males $(\mathrm{OR}=0.61,95 \% \mathrm{Cl}: 0.39-0.96)$ ). Additionally, animals reared under free system were at higher risk of exposure $(\mathrm{OR}=$ $2.71(95 \% \mathrm{Cl}: 1.71-4.31))$ than those did not (OR = 0.39, $95 \mathrm{Cl}$ : 0.23-0.58)). Conversely, in goats, the disease prevalence didn't vary significantly by any of the included variables, however, the obtained OR for each subcategory revealed remarkable variations as noted in the locality, age, season, and rearing system. Regarding locality, animals sampled from Sohag had higher OR (OR = $1.62(95 \% \mathrm{Cl}: 0.92-2.85))$ than those from Assiut (OR $=0.62(95 \% \mathrm{Cl}: 0.35-1.09))$. Animals with age over 2 years had the highest OR (OR = $1.58(95 \% \mathrm{Cl}$ : 0.79-3.15)) followed by $1.5-2$ years old group (OR $=1.22$ (95\% Cl: 0.58-2.57)) and those sampled at winter season were at highest risk (OR = 2.78 (95\% Cl: 1.21-6.35)) compared to other sampling seasons (Table 1 ).

The nucleotide sequences of the ITS2 of $F$. gigantica and $F$. hepatica isolates reported in this study were deposited in NCBI under accession no MT423006.1 and MT423007.1, respectively. An identity equal to $99.07 \%$ was found between the sequences of the two reported isolates.

A $100 \%$ match of our F. gigantica ITS-2 was found when sequence alignment was conducted along with Egyptian water buffalo (AB553695.1), Burkinian cattle (AJ853848.2) and Kenyan cattle (EF612484.1). However, an identity equal to $99.79 \%$ was found with F. gigantica ITS-2 reported from cattle in Nigeria (MN608170.1) and Iran (JF432074.1). A range of $99.45 \%$ $99.72 \%$ identities was found compared to four $F$. gigantica isolates obtained from humans in Vietnam (EU260070.1; EU260059.1; EU260060.1; EU260078.1). On 
the other hand, only $92.05 \%$ and $93.88 \%$ identities were found when our $F$. gigantica ITS2 sequence aligned with the outgroup isolates Fascioloides magna and $F$. jacksoni obtained from the American cattle (KU232369.1) and Sri Lankan elephant (MN970006.1), respectively (Fig.1). Comparing $F$. hepatica sequence with another 15 sequences obtained from the $\mathrm{NCBI}$ database revealed presence of $100 \%$ identity with the Egyptian water buffalo (AB553734.1) and human (KP215282.1) isolates, Algerian cattle (MK212149.1), Australian cattle (MN970007.1), Chinese sheep (MH385386.1), Indian yak (KR911820.1) and Ecuadorian cattle (LC056929.1) ITS-2 sequences. However, lower identities accounted for 96\%, 99.63\%, 99.34\%, $99.76 \%$ and $99.80 \%$ compared to Egyptian water buffalo (MH385386.1) and sheep (KJ818276.1) and Iranian cattle (KT033697.1), sheep (KT921273.1) and goat (KF866252.1) isolates, respectively. Both Fasciolae isolates reported in this study were computed against Fasciola hybrid isolates ITS-2 sequences located at the GenBank. Our F. gigantica and $F$. hepatica shared identities of 99.23:99.04: 98.62 and 99.04: 99.23: 99.01 with the Egyptian water buffalo (AB553738.1 and AB553737.1) and Japanese cattle (AB207153.1) Fasciola sp._ITS-2 sequences, respectively. On the other hand, only $92.03 \%$ and $93.49 \%$ identities were found when our $F$. hepatica ITS2 sequence aligned with the outgroup isolates Fascioloides magna and $F$. jacksoni obtained from the American cattle (KU232369.1) and Sri Lankan elephant (MN970006.1), respectively (Fig.2).

\section{DISCUSSION}

Fascioliasis is a parasitic infection with a great adverse influence on animal's productivity and causing a widespread human zoonotic disease in several countries such as Egypt, Tunisia, Algeria, Botswana, Mauritania, Niger, Saudi Arabia, Iraq, Iran, Pakistan, China, Vietnam, Korea and Japan (Agatsuma et al., 2000; Ali et al., 2008; Amer et al., 2011; Amer et al., 2016; Amor et al., 2011a; Ashrafi et al., 2007; Ashrafi et al., 2006; Farjallah et al., 2009; Haridy et al., 2006; Huang et al., 2004; Itagaki et al., 2009; Khalifa et al., 2016; Mochankana and Robertson, 2018; Nguyen et al., 2012; Over et al., 1992; Sharma and Raina, 1989; Wajdi and Nassir, 1983). Hence, the main purpose of the current study was to evaluate the prevalence of Fasciola species infection among cattle and goats in Assiut and Sohag Governorates of Upper Egypt. The morphological and morphometrical characterization of Fasciola species in Egypt are greatly variable, consequently, the molecular and phylogenetic analysis is greatly needed (Ashour et al., 1999).

The current study revealed an infection rate of $5.1 \%$ with $F$. gigantica in cattle and $3.5 \%$ with $F$. hepatica in goats. Compared to previous rates reported from different Egyptian governorates, our study came the lowest. In southern Egypt, it was $68.89 \%$ and $30.32 \%$ for infection with $F$. gigantica and $F$. hepatica in slaughtered animals, respectively in Qena Governorate, (Hussein and Khalifa, 2010) and the prevalence of fascioliasis was $35 \%$ in slaughtered cattle in El-Minia Governorate (Dyab et al., 2019). In northern Egypt, a prevalence of $9.77 \%$ in cattle were found to be infected with Fasciola species in the Delta region (El-Tahawy et al., 2017). Also, the 
fasciolaiasis was recorded as $11.1 \%$ in Dakhla Oasis, Egypt (Arafa et al., 2018)

A significant higher infection rates were found in older than younger animals and females than males which disagreed with results of El-Tahawy et al. (2017). This discrepancy could be attributed to the effect caused by regular anthelmintic administration to younger animals that kept for meat production particularly before slaughtering. This strategy does not typically apply for animals of older ages. Likewise, the increased infection among females in this study could be associated with the stress frequently occur for females during different stages of pregnancy and lactations making them more liable to parasitism.

Seasonal variation has been noted for the disease in previous studies (Bloemhoff et 
Table 1: Prevalence of Fasciola gigantica infection and different associated risk factors in examined slaughtered cattle.

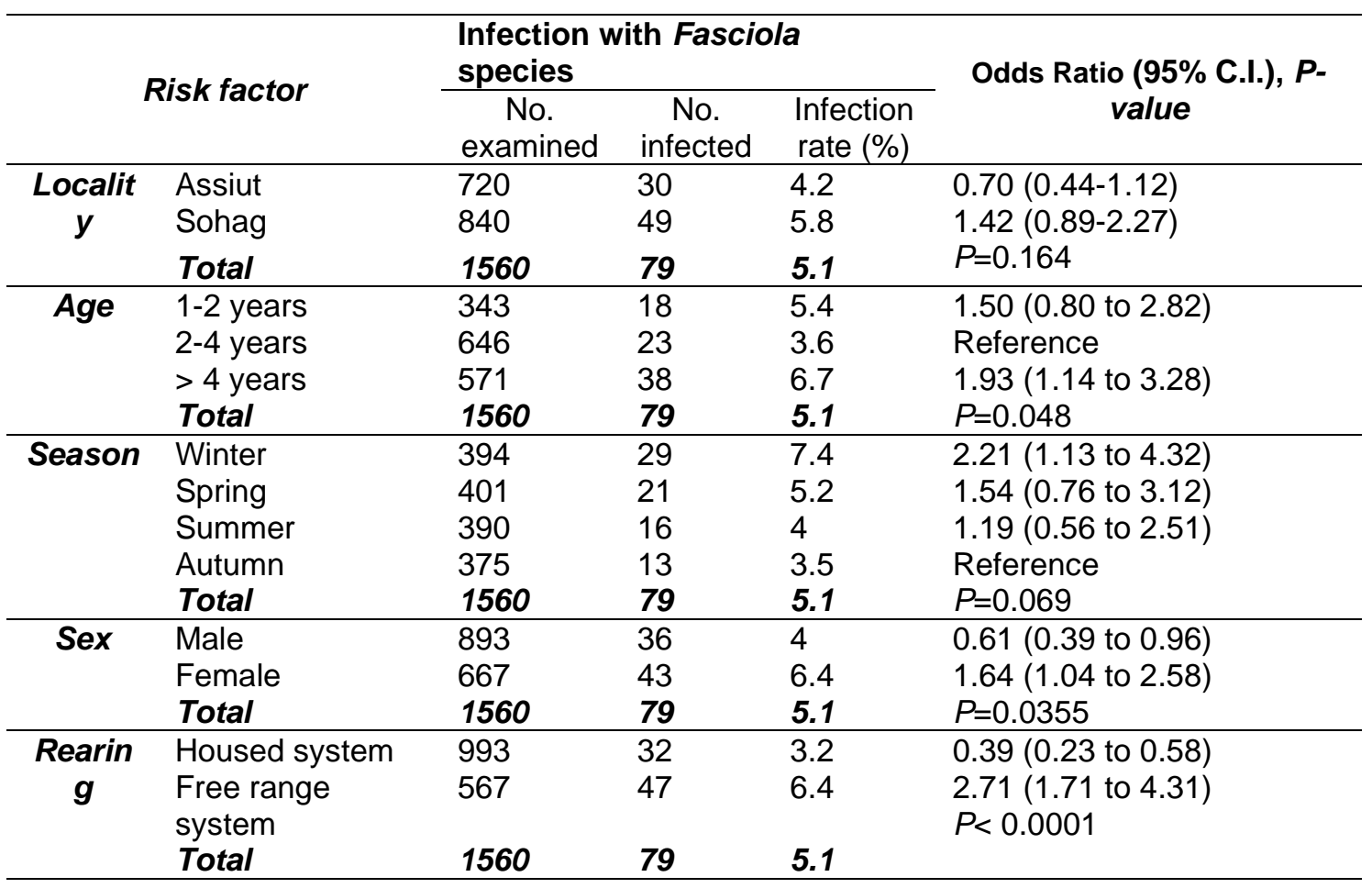

Table 2: Prevalence of Fasciola hepatica infection and different associated risk factors in examined slaughtered goats.

\begin{tabular}{|c|c|c|c|c|c|}
\hline & & Infection $w$ & h Fasciola & species & \\
\hline & isk factor & No. & No. & Infectio & Odds Ratio (99\% C.I.), P-value \\
\hline Locality & $\begin{array}{l}\text { Assiut } \\
\text { Sohag }\end{array}$ & $\begin{array}{l}690 \\
940\end{array}$ & $\begin{array}{l}18 \\
39\end{array}$ & $\begin{array}{l}2.6 \\
6.3\end{array}$ & $\begin{array}{l}0.62(0.35 \text { to } 1.09) \\
1.62(0.92 \text { to } 2.85)\end{array}$ \\
\hline & Total & 1630 & 57 & 3.5 & $P=0.105$ \\
\hline Age & $1-1.5$ years & 443 & 12 & 2.7 & Reference \\
\hline & $1.5-2$ years & 546 & 18 & 3.9 & $1.22(0.58$ to 2.57$)$ \\
\hline & $>2$ years & 641 & 27 & 4.2 & 1.58 (0.79 to 3.15$)$ \\
\hline & Total & 1630 & 57 & 3.5 & $P=0.39$ \\
\hline Season & Winter & 399 & 21 & 5.3 & 2.78 (1.21 to 6.35$)$ \\
\hline & Spring & 422 & 17 & 4.0 & 2.10 (0.89 to 4.92$)$ \\
\hline & Summer & 398 & 8 & 2.0 & Reference \\
\hline & Autumn & 411 & 11 & 2.7 & $1.41(0.56$ to 3.54$)$ \\
\hline & Total & 1630 & 57 & 3.5 & $P=0.056$ \\
\hline Sex & Male & 798 & 28 & 3.5 & $1(0.59$ to 1.71$)$ \\
\hline & Female & 832 & 29 & 3.5 & 0.99 (0.58 to 1.68$)$ \\
\hline & Total & 1630 & 57 & 3.5 & $P=1.00$ \\
\hline Rearing & Housed system & 893 & 26 & 2.6 & $0.68(0.40$ to 1.16$)$ \\
\hline & Free range & 737 & 31 & 4.0 & 1.46 (0.86 to 2.49$)$ \\
\hline & system & & & & $P=0.176$ \\
\hline & Total & 1630 & 57 & 3.5 & \\
\hline
\end{tabular}




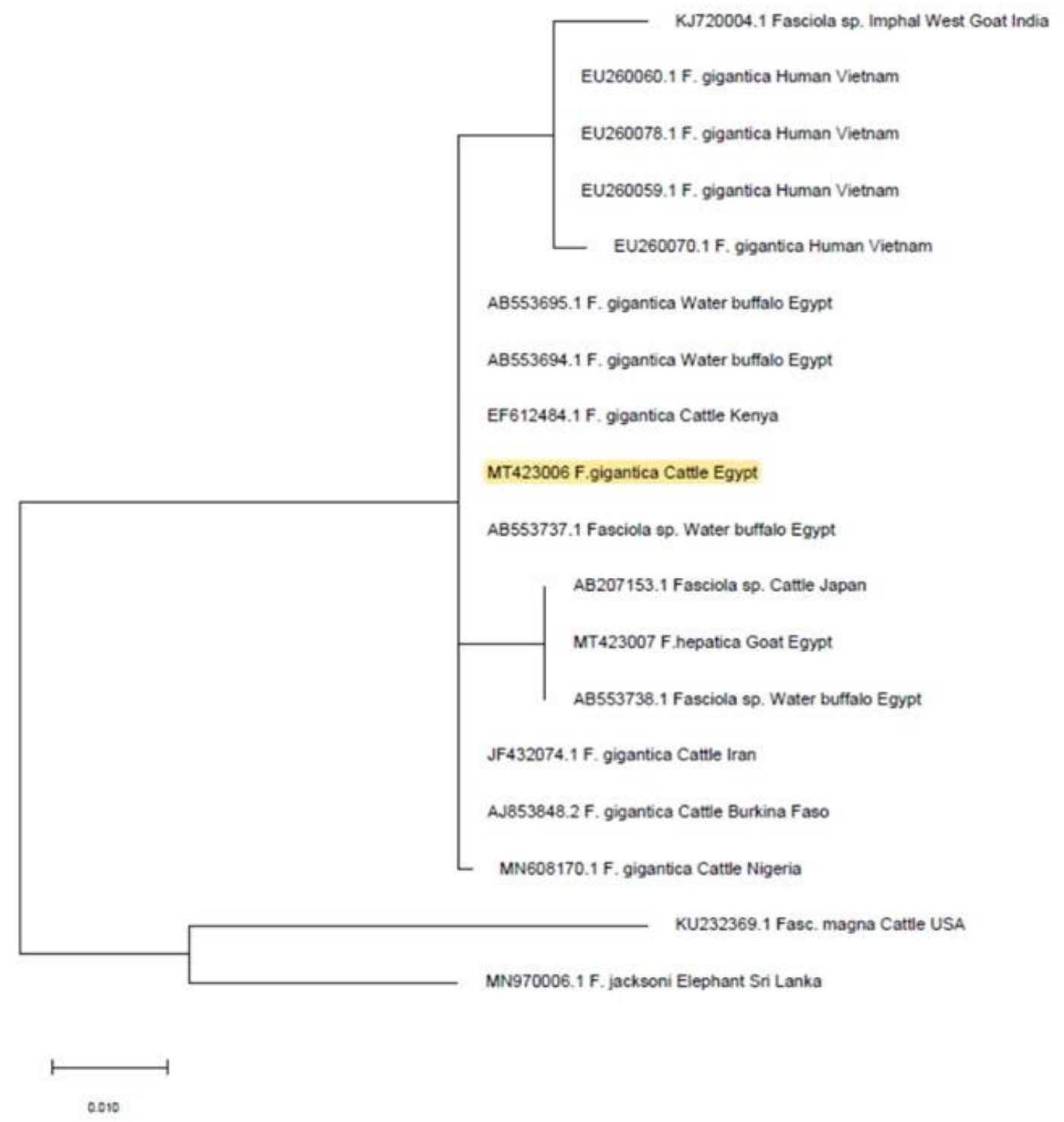

Fig.1. Phylogenetic tree inferred from F. gigantica ITS-2 sequences. F. gigantica isolate reported in this study is highlighted. A total of 18 different nucleotide sequences were used to construct the tree using MEGAX. The evolutionary history was inferred by using the Maximum Likelihood method and Tamura-Nei model. Initial trees for the heuristic search were obtained by applying the Neighbor-Joining method to a matrix of pairwise distances estimated using the Tamura-Nei model. 


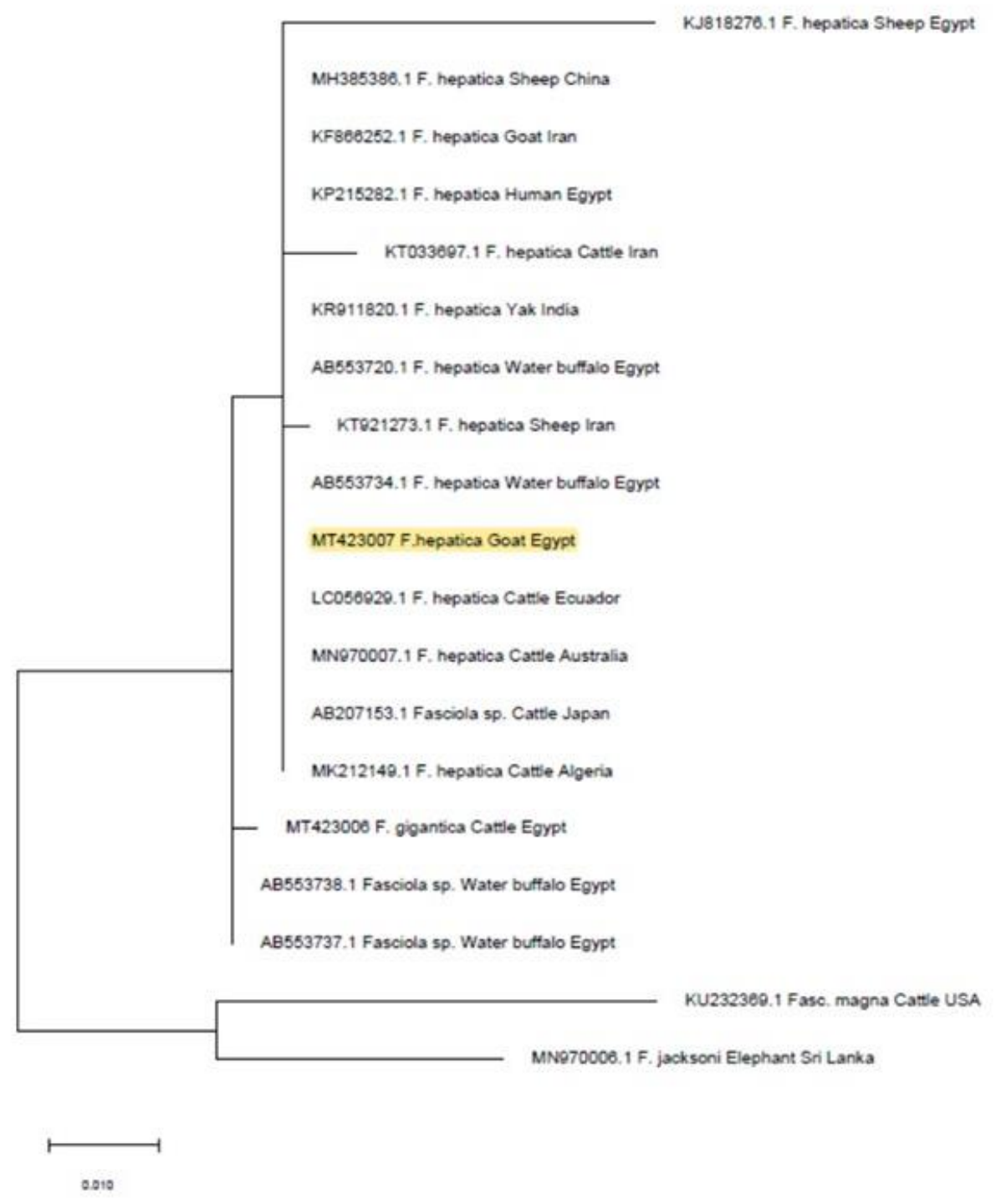

Fig.2. Phylogenetic tree inferred from F. hepatica ITS-2 sequences. F. hepatica isolate reported in this study is highlighted. A total of 19 different nucleotide sequences were used to construct the tree using MEGAX. The evolutionary history was inferred by using the Maximum Likelihood method and Tamura-Nei model. Initial trees for the heuristic search were obtained by applying the Neighbor-Joining method to a matrix of pairwise distances estimated using the Tamura-Nei model.

al., 2015; Dyab et al., 2019; cailliaudi, Pseudosuccinea columella and Maqbool et al., 2002; Pfukenyi and Biomphalaria alexandrina (Arafa et al., 2018; Mukaratirwa, 2004; Soliman, 2008). Dar et al., 2005). These snails are widely Likewise, in our study, a seasonal pattern distributed in Egypt however, their was observed for the disease in both cattle abundance, distribution and role in fasciolosis and goats with increasing infection rate transmission needs to be re-evaluated in appeared in the winter and spring. Under response to the recent climatic changes. A Egyptian settings, Fasciolae utilize several convincing explanation for the documented snails as intermediate hosts such as Radix seasonal pattern of the disease in upper natalensis, Galba truncatula, Lymnaea Egypt is required however the fact that 
immature stages of the parasites takes long time to reach adult stage since engulfed by the host and also the infected animals keep the adult fasciolae for years in the biliary tract (Robinson and Dalton, 2009), a definite tracking of the timing of the infection likely impossible without a comprehensive multifactorial study.

In the present study, animals reared on free range system were significantly higher than housed cattle because they are highly exposed to the infection on free grazing particularly on sides of canals, banks and rivers and these findings are is agreed partially with those obtained by ElTahawy et al. (2017).

The results of the present studies agreed with those of previous studies in Iranshahr, Iran (Hashemi et al., 2015) where the fascioliasis in Slaughtered cattle was $7.82 \%$ with higher prevalence rates between cattle over 1 year old than younger, males than females, in winter than other seasons and exogenous than indigenous breeds. Also agreed with that conducted in Tonekabon, Iran, where high prevalence rates of fascioliasis in buffaloes (12.76\%) and goats (6.97\%) (Amor et al., 2011b) were found. Moreover, in eastern Botswana, the prevalence of $F$. gigantica infection in beef cattle was very low $(0.74 \%)$ in comparison to the current study, but agreed in that, the prevalence of fascioliasis was significantly higher in adult cattle than youngers (Mochankana and Robertson, 2018). Also, in central Vietnam, prevalence of fascioliasis was $45.3 \%$ with a higher prevalence rates observed in adult cattle than calves and in rainy season than in dry season (Nguyen et al., 2012).
The present study revealed that fascioliasis was $3.5 \%$ in examined goats and was higher between older than young goats, in winter than other seasons, among males than females and in freely reared goats than housed animals. The prevalence of fascioliasis in goats in Egypt was ranged from low $(0.89 \%)$ in Giza Governorate (Hassan et al., 2019) to high (14.6\%) in AlSharqiyah Governorate (El-Azazy and Fayek, 1990). Also, fascioliasis prevalence in goats was 6.6-28.75\% in Pakistan (IrfanUllah et al., 2016; Tasawar et al., 2007), $14.14 \%$ in Turkey (Çelik and ÇELIK, 2018), 6.2\% in Nigeria (Abah et al., 2019) and 6.97\% in north region of Iran (Amor et al., 2011b).

In the present work, Fasciola isolates of cattle and goats from Assiut and Sohag governorates (Upper Egypt) were genetically identified by sequencing of the ITS2 gene, and the obtained sequences were similar and identical to sequences of Fasciola species of previously identified isolates of $F$. hepatica, and F. gigantica (Agatsuma et al., 2000; Ali et al., 2008; Farjallah et al., 2009; Itagaki et al., 2005; Periago et al., 2004; Rokni et al., 2010). Interestingly, phylogenetic analysis showed that the isolates reported in this study fall with other animal Fasciolae isolates in the same clade. Similarly, the analysis showed that $F$. gigantica fall in the same clade with four human fasciolae isolates previously obtained from Vietnam. Likewise, Fasciola hepatica sequence was found to share one clade with a one isolate recently recovered from human in Assiut Governorate (Khalifa et al., 2016). These similarities demonstrate the close relatedness which indicating that the isolates likely originated from a common ancestor.

In conclusion, the present study showed that Fasciola species is circulating 
among animals in Assiut and Sohag Governorates. Though low prevalence was demonstrated in comparison with other districts in Egypt, appropriate control measures are required to completely eradicate the disease among animal reservoirs in order to avoid any possible public health threatening. The zoonotic burden of the disease among humans residing the survey areas and a further study to determine the contribution of different snails in the disease spread is needed.

\section{Acknowledgements}

The authors are grateful to the veterinarians of the Assiut and Sohag abattoirs for their help in providing data and sample collection throughout the study.

\section{Conflict of interest:}

All authors declare that there is no any conflict of interest.

\section{References}

Abah, A., Wokem, G., Sounyo, I., 2019. Fasciola infection in goats slaughtered from Port Harcourt metropolis Rivers State, Nigeria. Int J One Health 5, 76-80.

Agatsuma, T., Arakawa, Y., Iwagami, M., Honzako, Y., Cahyaningsih, U., Kang, S.Y., Hong, S.-J., 2000. Molecular evidence of natural hybridization between Fasciola hepatica and F. gigantica. Parasitol. Int. 49, 231-238.

Ali, H., Ai, L., Song, H., Ali, S., Lin, R., Seyni, B., Issa, G., Zhu, X., 2008. Genetic characterisation of Fasciola samples from different host species and geographical localities revealed the existence of $F$. hepatica and F. gigantica in Niger. Parasitol. Res. 102, 1021-1024.
Amer, S., Dar, Y., Ichikawa, M., Fukuda, Y., Tada, C., Itagaki, T., Nakai, Y., 2011. Identification of Fasciola species isolated from Egypt based on sequence analysis of genomic (ITS1 and ITS2) and mitochondrial (NDI and COI) gene markers. Parasitol. Int. 60, 5-12.

Amer, S., ElKhatam, A., Zidan, S., Feng, Y., Xiao, L., 2016. Identity of Fasciola spp. in sheep in Egypt. Parasit Vectors 9, 623.

Amor, N., Farjallah, S., Salem, M., Lamine, D.M., Merella, P., Said, K., Slimane, B.B., 2011a. Molecular characterization of Fasciola gigantica from Mauritania based on mitochondrial and nuclear ribosomal DNA sequences. Exp. Parasitol. 129, 127-136.

Amor, N., Halajian, A., Merella, P., Farjallah, S., Said, K., Slimane, B., 2011b. Genetic characterization of Fasciola spp. from Tonekabon City (northern Iran) based on the ribosomal internal transcribed spacer regions. Pak J Zool 43, 1061-1067.

Arafa, W. M., et al. "Fasciola hepatica infections in cattle and the freshwater snail Galba truncatula from Dakhla Oasis, Egypt." Journal of helminthology 92.1 (2018): 56.

Ashour, A.A., Essa, Z., Khalil, A., El-Sherif, E., 1999. Studies on the liver fluke Fasciola in Egypt: I-Morphological and Morphometrical studies. J Egypt Soc Parasitol 29, 979-996.

Ashrafi, K., Massoud, J., Naieni, K.H., JoAfshani, M., Mahmoodi, M., Ebadati, N., Rezvani, S., Artigas, P., Bargues, M., MasComa, S., 2007. Nuclear ribosomal DNA ITS2 sequence characterization of Fasciola hepatica and Galba truncatula. Iran J Public Health, 42-49.

Ashrafi, K., Valero, M., Panova, M., Periago, M., Massoud, J., Mas-Coma, S., 2006. Phenotypic analysis of adults of Fasciola 
hepatica, Fasciola gigantica and intermediate forms from the endemic region of Gilan, Iran. Parasitol. Int. 55, 249260.

Bloemhoff, Y., Forbes, A., Danaher, M., Good, B., Morgan, E., Mulcahy, G., Sekiya, M., Sayers, R., 2015. Determining the prevalence and seasonality of Fasciola hepatica in pasture-based dairy herds in Ireland using a bulk tank milk ELISA. Ir. Vet. J. 68, 16.

Çelik, Ö.Y., ÇELIK, $\quad$ B.A., 2018. Investigation of the Prevalence of Fasciola hepatica in Small Ruminants in the Siirt Region, Turkey. Iran J Parasitol 13, 627.

Charan, J., Biswas, T., 2013. How to calculate sample size for different study designs in medical research? Indian $\mathrm{J}$. Psychol. Med. 35, 121.

Choe, S.-E., Nguyen, T.T.-D., Kang, T.-G., Kweon, C.-H., Kang, S.-W., 2011. Genetic analysis of Fasciola isolates from cattle in Korea based on second internal transcribed spacer (ITS-2) sequence of nuclear ribosomal DNA. Parasitol. Res. 109, 833-839.

Dar, Y., Rondelaud, D., Dreyfuss, G., 2005. Update of fasciolosis-transmitting snails in Egypt (review and comment). J. Egypt. Soc. Parasitol. 35, 1.

Dyab, A.K., Ahmed, H.A., Hefnawy, Y.A., Abdel-Aziz, A.R., Gomaa, M.M., 2019. Prevalence of Tissue Parasites in Cattle and Buffaloes Slaughtered in El-Minia Governorate Abattoirs, Egypt. PSM Vet Res 4, 49-58.

El-Azazy, O., Fayek, S., 1990. Seasonal pattern of Fasciola gigantica and Cysticercus tenuicollis infections in sheep and goats in Egypt. Bull Anim Health Prod Afr 38, 369-373.
El-Tahawy, A.S., Bazh, E.K., Khalafalla, R.E., 2017. Epidemiology of bovine fascioliasis in the Nile Delta region of Egypt: Its prevalence, evaluation of risk factors, and its economic significance. Vet world 10, 1241.

Farjallah, S., Sanna, D., Amor, N., Mehel, B.B., Piras, M.C., Merella, P., Casu, M., Curini-Galletti, M., Said, K., Garippa, G., 2009. Genetic characterization of Fasciola hepatica from Tunisia and Algeria based on mitochondrial and nuclear DNA sequences. Parasitol. Res. 105, 1617.

Haridy, F., El-Sherbiny, G., Morsy, T., 2006. Some parasitic flukes infecting farm animals in Al-Santa Center, Gharbia Governorate, Egypt. J. Egypt. Soc. Parasitol. 36, 259-264.

Hashemi, S.H., Anvari, D., Sargazi, D., 2015. Prevalence of Fasciolahepatica in Slaughtered Cattles in Iranshahr's Slaughterhouse in 2013. DAV Int J Sci vol 4 issue 2

Hashimoto, K., Watanobe, T., Liu, C., Init, I., Blair, D., Ohnishi, S., Agatsuma, T., 1997. Mitochondrial DNA and nuclear DNA indicate that the Japanese Fasciola species is $F$. gigantica. Parasitol. Res. 83, 220-225.

Hassan, N.M., Farag, T.K., El Ezz, N.M.A., Abou-Zeina, H.A., 2019. Prevalence assessment of gastrointestinal parasitic infections among goats in Giza Governorate, Egypt. Bull Natl Res Cent 43, 1-7.

Huang, W., He, B., Wang, C., Zhu, X., 2004. Characterisation of Fasciola species from Mainland China by ITS-2 ribosomal DNA sequence. Vet. Parasitol. 120, 75-83.

Hussein, A.-N.A., Khalifa, R.M., 2010. Phenotypic description and prevalence of Fasciola species in Qena Governorate, Egypt with special reference to a new strain of 
Fasciola hepatica. J King Saud Univ Sci 22, 1-8.

IrfanUllah, M.F.N., Jadoon, A.A.K., Tabassum, S., 2016. Prevalence of Fasciola hepatica in Domesticated Cattle of District Karak, Khyber Pakhtunkhwa, Pakistan. Sciences 10, 85-91.

Itagaki, T., Kikawa, M., Sakaguchi, K., Shimo, J., Terasaki, K., Shibahara, T., Fukuda, K., 2005. Genetic characterization of parthenogenic Fasciola sp. in Japan on the basis of the sequences of ribosomal and mitochondrial DNA. Parasitology 131, 679-685.

Itagaki, T., Sakaguchi, K., Terasaki, K., Sasaki, O., Yoshihara, S., Van Dung, T., 2009. Occurrence of spermic diploid and aspermic triploid forms of Fasciola in Vietnam and their molecular characterization based on nuclear and mitochondrial DNA. Parasitol. Int. 58, 8185.

Khalifa, R., Hassanin, A.S., Monib, M., Yones, D.A., EL-Ossily, N., AbdelRahman, A.S., 2016. Molecular and Phylogenic Characterization of Fasciola hepatica from Assiut, Egypt based on nuclear ribosomal DNA sequences. J Med Sci Clin Res 4, 9007-9016.

Knubben-Schweizer, G., Torgerson, P.R., 2015. Bovine fasciolosis: control strategies based on the location of Galba truncatula habitats on farms. Vet. Parasitol. 208, 7783.

Kumar, S., Stecher, G., Li, M., Knyaz, C., Tamura, K., 2018. MEGA X: molecular evolutionary genetics analysis across computing platforms. Mol. Biol. Evol. 35, 1547-1549.

Lin, R., Dong, S., Nie, K., Wang, C., Song, H., Li, A., Huang, W., Zhu, X., 2007.
Sequence analysis of the first internal transcribed spacer of rDNA supports the existence of the intermediate Fasciola between $F$. hepatica and F. gigantica in mainland China. Parasitol. Res. 101, 813 817.

Liu, G.-H., Gasser, R.B., Young, N.D., Song, H.-Q., Ai, L., Zhu, X.-Q., 2014. Complete mitochondrial genomes of the intermediate form'of Fasciola and Fasciola gigantica, and their comparison with $F$. hepatica. Parasit Vectors 7, 150.

Luton, K., Walker, D., Blair, D., 1992. Comparisons of ribosomal internal transcribed spacers from two congeneric species of flukes (Platyhelminthes: Trematoda: Digenea). Mol. Biochem. Parasitol. 56, 323-327.

Madeira, F., Park, Y.M., Lee, J., Buso, N., Gur, T., Madhusoodanan, N., Basutkar, P., Tivey, A.R., Potter, S.C., Finn, R.D., 2019. The EMBL-EBI search and sequence analysis tools APIs in 2019. Nucleic Acids Res. 47, W636-W641.

Maqbool, A., Sikandar Hayat, C., Akhtar, T., Hashmi, H.A., 2002. Epidemiology of fasciolosis in buffaloes under different managemental conditions. Veterinarski arhiv 72, 221-228.

Marcilla, A., Bargues, M., Mas-Coma, S., 2002. A PCR-RFLP assay for the distinction between Fasciola hepatica and Fasciola gigantica. Mol. Cell. Probes 16, 327-333.

Mas-Coma, S., Bargues, M.D., Valero, M., 2005. Fascioliasis and other plant-borne trematode zoonoses. Int. J. Parasitol. 35, 1255-1278.

Mochankana, M.E., Robertson, I.D., 2018. Cross-sectional prevalence of Fasciola 
gigantica infections in beef cattle in trematodiases. Philos Trans $\mathrm{R}$ Soc Lond $\mathrm{B}$ Botswana. Trop. Anim. Health Prod. 50, Biol Sci 364, 2763-2776. 1355-1363.

Moghaddam, A., Massoud, J., Mahmoodi, M., Mahvi, A., Periago, M., Artigas, P., Fuentes, M., Bargues, M., Mas-Coma, S., 2004. Human and animal fascioliasis in Mazandaran province, northern Iran. Parasitol. Res. 94, 61-69.

Nguyen, S.T., Nguyen, D.T., Van Nguyen, T., Huynh, V.V., Le, D.Q., Fukuda, Y., Nakai, Y., 2012. Prevalence of Fasciola in cattle and of its intermediate host Lymnaea snails in central Vietnam. Trop. Anim. Health Prod. 44, 1847-1853.

Nyindo, M., Lukambagire, A.-H., 2015. Fascioliasis: an ongoing zoonotic trematode infection. BioMed res int 2015.

Over, H.J., Jansen, J., Van Olm, P., 1992. Distribution and impact of helminth diseases of livestock in developing countries. Food \& Agriculture Org.

Periago, M., Artigas, P., Khoubbane, M., Moghaddam, A., Ashrafi, K., Mansoorian, A., Masoud, J., Bargues, M., Mas-Coma, S., 2004. Genotypic analysis of adult liver flukes from Iran based on the ribosomal DNA markers ITS-1 and ITS-2. IX European Multicolloquium of Parasitology, 18-23 July 2004, Valencia, Spain, 286287.

Pfukenyi, D.M., Mukaratirwa, S., 2004. A retrospective study of the prevalence and seasonal variation of Fasciola gigantica in cattle slaughtered in the major abattoirs of Zimbabwe between 1990 and 1999. Onderstepoort J. Vet. Res. 71, 181-187.

Robinson, M.W., Dalton, J.P., 2009. Zoonotic helminth infections with particular emphasis on fasciolosis and other
Rokni, M.B., Mirhendi, H., Mizani, A., Mohebali, M., Sharbatkhori, M., Kia, E.B., Abdoli, H., Izadi, S., 2010. Identification and differentiation of Fasciola hepatica and Fasciola gigantica using a simple PCRrestriction enzyme method. Exp. Parasitol. 124, 209-213.

Sharma, R., Raina, O., 1989. Studies on the prevalence and laboratory transmission of fascioliasis in animals in the Kashmir valley. Br. Vet. J. 145, 57-61.

Shoriki, T., Ichikawa-Seki, M., Suganuma, K., Naito, I., Hayashi, K., Nakao, M., Aita, J., Mohanta, U.K., Inoue, N., Murakami, K., 2016. Novel methods for the molecular discrimination of Fasciola spp. on the basis of nuclear protein-coding genes. Parasitol. Int. 65, 180-183.

Soliman, M.F., 2008. Epidemiological review of human and animal fascioliasis in Egypt. $J$ Infect Dev Ctries 2, 182-189.

Soulsby, E. 1982. Helminths, Arthropods and Protozoa of Domesticated Animals (7th Edn.) Baillière Tindall (London).

Soulsby, E. 1982. Helminths, Arthropods and Protozoa of Domesticated Animals (7th Edn.) Baillière Tindall (London).

Tamura, K., Nei, M., 1993. Estimation of the number of nucleotide substitutions in the control region of mitochondrial DNA in humans and chimpanzees. Mol. Biol. Evol. 10, 512-526.

Tasawar, Z., Minir, U., Hayat, C., Lashari, M., 2007. The prevalence of Fasciola hepatica in goats around Multan. Infection 32, 23.50.

Wajdi, N., Nassir, J., 1983. Studies on the parasitic helminths of slaughtered animals in Iraq: I. Parasitic helminths of the liver of 
herbivores. Ann. Trop. Med. Parasitol. 77, 583-585.

White, B.A., 1993. PCR protocols: current methods and applications, Vol 15. Springer Science \& Business Media. 
الملخص العربي

الانتشار والتحليل الوراثي لأنواع المتورقة (الديدان الكبدية) في صعيد مصر بناءً على التسلسل

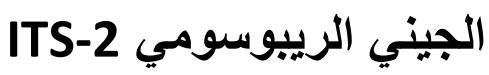

أحمد عبد العظيم1 و عامر راغب عبد العزيز2 ورضا البسطويسي ابراهيم خلف الله@3 ومصطفى أبو شهبة 4-5

$$
\begin{aligned}
& \text { 1قسم الطفيليات -كلية الطب البيطري - جامعة أسوان } \\
& \text { 2قسم الطفيليات -كلية الطب البيطري - جامعة سوهاج } \\
& \text { 3@ قسم الطفيليات -كلية الطب البيطري - جامعة كفر الثيخ } \\
& 4 \text { قسم الأمر اض المشتركة ـ كلية الطب البيطري -جامعة أسيوط }
\end{aligned}
$$

5 قسم الباطنة ــالامر اض المعديةــ مدرسة الطب -جامعة واشنطن- سانت لويس ـ الولايات المتحدة الامريكية

\section{الملخص}

داء المتورقة الكبدية (الفاثيو لا) هو مرض طفيلي حيواني هام حيث يتسبب في خسائر اقتصادية سنوية تقدر بأكثر من 3 مليار ات دولار أمريكي في الحيوانات وكذلك مخاطر العدوى للبشر في أكثر من 180 مليون

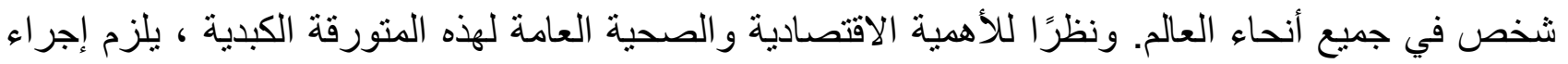
تقييم دوري لانتشار ها وعوامل الخطر المرتبطة بها بالإضافة إلى الارنباط التطوري. في البحث المعروض،

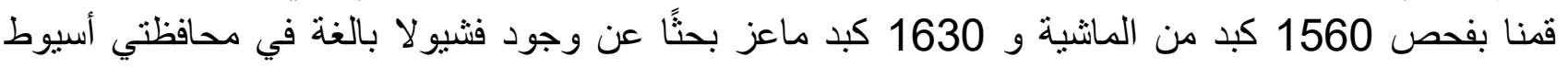

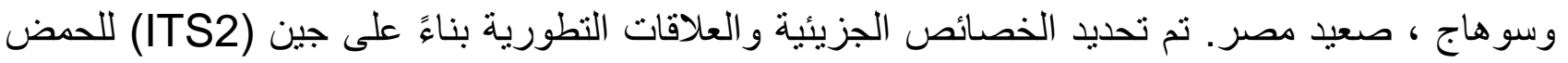

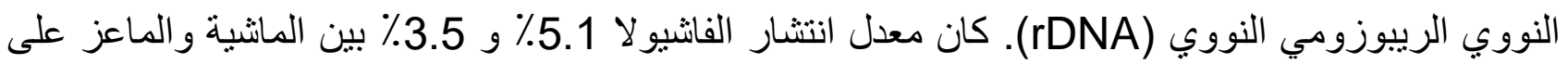

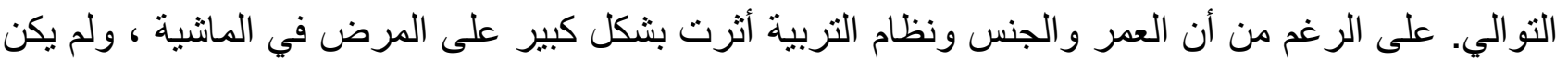

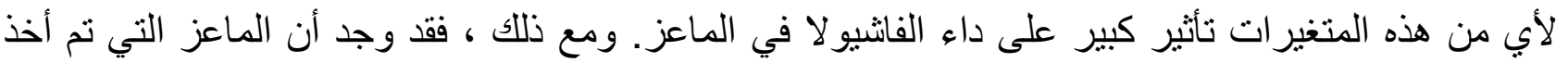

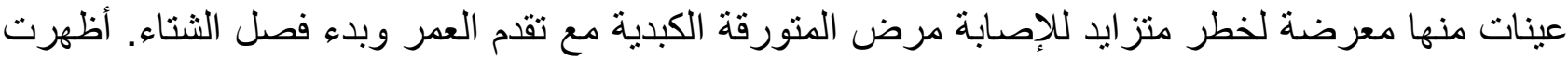

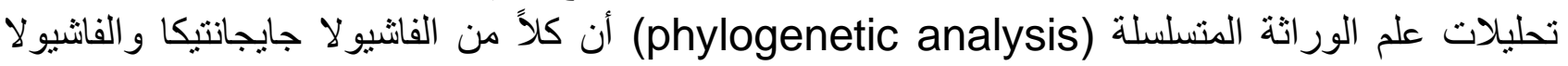
هيباتيكا في هذه الدراسة لهما سلف مشترك وأنهما يقعان في فرع واحد مع العديد من الفاثشيو لا المصرية و العالمية التي تم الإبلاغ عنها سابقًا من الحيوانات و البشر. توضح هذه الدراسة أن المرض ينتشر حاليًا بين الحيوانات في محافظتي أسيوط وسوهاج مما يستدعي الحاجة الملحة لتطبيق إجراءات المكافحة المناسبة لئنة بالإضافة إلى تقييم العبء الحيو اني المستمر المحتمل على الأشخاص المقيمين في هذه المناطق. 
